Article

\title{
Law and Politics in River Basin Management: The Implementation of the Water Framework Directive in The Netherlands
}

\author{
Erik Mostert \\ Department of Water Management, Delft University of Technology, 2628 CN Delft, The Netherlands; \\ e.mostert@tudelft.nl
}

Received: 9 October 2020; Accepted: 27 November 2020; Published: 30 November 2020

\begin{abstract}
This article discusses the implementation of the Water Framework Directive (WFD) in the Netherlands and shows how law and politics combine in river basin management. Initially, the implementation of the WFD in the Netherlands was approached as a technical and administrative issue, handled by water quality and ecology experts, but, in 2003, this approach was broken open by the agricultural sector, who feared stricter regulation. Subsequently, the environmental objectives of the WFD were set as low as possible and they play no role when authorising new projects. In July 2015, however, the European Court of Justice determined that the environmental objectives have a binding effect and that Member States have to refuse authorisation of projects that jeopardise the achievement of these objectives. This example shows the important role that law as a social phenomenon or "field" can play in river basin management, provided the courts enjoy sufficient social and political support and function relatively independently, as they do in the Netherlands. The article discusses the origin of the juridical field and its relation with politics and concludes that, to understand river basin management fully, it is essential to understand how (water) law functions.
\end{abstract}

Keywords: water framework directive; European Union; the Netherlands; water law; politics

\section{Introduction}

On 1 July 2015, the Court of Justice of the European Union, or in short the European Court of Justice, issued a preliminary ruling in the case between the Bund für Umwelt und Naturschutz Deutschland (a German environmental NGO) and the Federal Republic of Germany concerning the deepening of the Weser estuary [1]. The deepening would most likely have some negative effects on the estuary. This might conflict with the Water Framework Directive (WFD) since one of the environmental objectives of the WFD is to prevent deterioration of the water status. The case was brought before the Federal Administrative Court, but it was not clear for this court whether the negative effects count as "deterioration" and whether this would imply that deepening cannot be authorised. Hence, the court decided to stay the proceedings and referred these two questions to the European Court of Justice for a preliminary ruling.

The European Court ruled that the environmental objectives of the WFD are not mere management objectives but have a binding effect, and that Member States have to refuse authorisation for projects that jeopardise the achievement of these objectives. In the Netherlands, however, individual projects are not assessed against the environmental objectives of the WFD [2-4]. Instead, the environmental objectives have to be incorporated into the different water plans and the different water plans subsequently have to be implemented. According to the minister for water management, this would ensure that the environmental objectives are reached [5]. This is, however, questionable.

The purposes of this article are, first, to describe the implementation of the WFD in the Netherlands, focusing on the environmental objectives, and explain why the Netherlands do not comply with the 
Weser ruling and what the consequences of this could be. Much has already been written about the implementation of the WFD in the Netherlands (e.g., [6-16]), but this body of literature only covers the period until 2009, when the first river basin management plans were adopted, and does not go into detail concerning the legal aspects. There is also a smaller body of legal literature, but this literature does not discuss the political aspects of implementation (e.g., $[2,17,18])$. In this article, I try to integrate these two perspectives in order to provide a more comprehensive view.

The second purpose of this article is to show the importance of law and especially the courts in river basin management. This importance has been recognised before, but law is often conceived as a normative domain distinct from politics [19], as an instrument of political domination [20], or as a management tool [21,22]. In this article, I follow the approach of the French sociologists Pierre Bourdieu $[23,24]$, who conceives law as a relatively independent social "field" with its own actors and structure.

The article is based to a large extent on literature study. In order not to miss any important publications on the implementation of the WFD in the Netherlands, two literature searches in Google scholar were conducted, using the search terms "Aquarein" (see below; 102 hits) and "C-461/13" (the number of the Weser ruling) AND "Kaderrichtlijn water" (WFD in Dutch; 12 hits). In addition, original sources were consulted, such as the WFD itself, the Weser ruling, the most relevant Dutch laws and byelaws, and the most relevant policy documents. Furthermore, I have been involved in an advisory capacity in the implementation of the WFD (e.g., [25-27]) and, as a result, I have interacted directly with some key stakeholders in the implementation process. This helped me with the interpretation of the texts found. Finally, I conducted a literature search in Google scholar concerning the use of Bourdieu's approach in the field of water resources management, using the search terms "The force of law: towards a sociology of the juridical field" (the key reference) AND "water resources". This yielded 21 results, most of which mentioned Bourdieu only in passing or focused on other issues than water resources and none focused on the role of courts.

The article is structured as follows. In the next section, the WFD and its environmental objectives are introduced. In Section 3, the implementation process in the Netherlands until 2015 is described. This is followed in Section 4 by a discussion of the Weser ruling and the Dutch reaction to it. In Section 5 , the importance of water law for river basin water management and the link with politics are discussed. The article ends with a short conclusion.

\section{The Water Framework Directive and Its Environmental Objectives}

The WFD has been interpreted as an important innovation in European water governance [28] and as a missed opportunity for introducing integrated water resources management [29]; as an ambiguous document that tries to combine expert-based approaches with participatory approaches [30] and strict regulatory approaches with flexible economic approaches [31]; and as the victim of political convenience and vested interests [32]. However, whatever else it is, the WFD is also an EU directive.

EU directives are binding upon the Member States as to the result to be achieved, but the Member States can choose the form and methods to achieve these results themselves (art. 288 Treaty on the functioning of the European Union, TfEU). With the exception of provisions that are specific and leave little room for discretion, they do not apply directly and first have to be transposed into binding national law. In this respect, they differ from other EU law, which applies directly. As the European Court of Justice decided in 1963 in the Van Gend \& Loos case, the "Community constitutes a new legal order ( ... ), the subjects of which comprise not only Member States but also nationals. ( ... ) Community law therefore not only imposes obligations on individuals but it also intended to confer upon them rights which become part of their legal heritage" (quoted in [33], p. 60). (Interestingly, there was nothing in the treaties founding the (predecessors of the) EU that compelled the Court to interpret EU law in this way. Arguably, it was a political decision couched in legal terms, to promote European integration by legal means $([33,34])$.) 
Like other EU law, directives are enforced strictly. If a Member State does not implement EU law correctly, the European Commission can start an infringement procedure, and if the Member State does not give a satisfactory explanation, the Commission can issue a "reasoned opinion", indicating the changes the Member State has to make by which date. If the Member State does not comply, the Commission can bring the Member State before the European Court of Justice. If the Member State does not implement the Court's decision, the Commission can bring the case before the Court for a second time, and then the Court can impose a lump sum or a penalty payment (art. 258 and $260 \mathrm{TfEU}$ ). Member States may also be brought before the Court by other Member States, but this happens rarely (art. 259 TfEU). Furthermore, national courts have to interpret rules of national law in a way that is consistent with EU law and they have to apply some rules of EU law directly. If they have questions concerning the correct interpretation of EU law, they may refer these questions to the European Court for a preliminary ruling, as happened in the Weser case (art. $267 \mathrm{TfEU}$ ).

In 2018, the most recent year for which data are available, the Commission received 339 complaints on incorrect implementation of EU environmental law, started 73 new infringement procedures, and referred 10 cases to the European Court of Justice. In addition, the Court issued three preliminary rulings [35]. The fines imposed by the Court can be high. For instance, on 31 May 2018, the Court ordered Italy to pay a lump sum penalty of $€ 25$ million for non-compliance with the Urban wastewater treatment directive and a further penalty of $€ 30$ million for every six months of delay until full compliance was achieved [36].

While the legal status of EU directives is generally clear, the same could not be said of the environmental objectives of the WFD. According to article 4 of the WFD, Member States have to prevent deterioration of the water status and protect, enhance and restore all water with the aim of achieving a "good water status" by 2015. For surface water bodies, good water status means a good chemical status as defined by the Environmental Quality Standards Directive, and a good ecological status, defined as a slight deviation from undisturbed conditions. For water bodies designated as artificial or heavily modified, the ecological objective is a good ecological potential, which takes into consideration their artificial or heavily modified character. For groundwater bodies, a good water status means a good chemical status as defined by the Groundwater directive (2006/118/EC), and a good quantitative status, e.g., no over-abstraction (annex V WFD). If Member States cannot reach a good status by 2015 , they may extend deadlines maximally twice by six years, but only if reaching the objectives in time is technically not feasible or disproportionately expensive. In addition, they may set lower objectives on the same grounds.

This description of the environmental objectives is only an incomplete summary. As printed in the Official Journal, article 4 is nearly three pages long, annex V 31 pages, the Environmental Quality Standards Directive 14 pages, and the Groundwater directive 13 pages. Still, until the Weser ruling of 1 July 2015, it was not clear whether the environmental objectives entailed an obligation of a result or only an obligation of effort. In other words, do Member Status have to prevent deterioration and reach a good status, or do they only have to make a serious effort?

This ambiguity in the WFD can be explained by how it was developed $([13,37]$, Annex V). Proposals for new EU directives on environmental issues are drafted by the European Commission, usually after extensive consultations and lobbying, and have to be adopted by both the Council (the environmental ministers of the Member States), and, since 1 May 1999, the European Parliament. The Council was against binding environmental objectives, while the European Parliament was in favour. Eventually, a conciliation procedure was necessary, involving representatives of the Commission, the Council and the European Parliament (art. 294 TfEU). The compromise reached was to formulate the objective of reaching a good status as an obligation of effort (Member States have to take action "with the aim" of achieving a good status), and the no-deterioration objective as an obligation of result (Member States shall implement the "necessary measures" to prevent deterioration; see also recital 25 of the WFD). 


\section{Implementation of the WFD until 2015}

In the Netherlands, the WFD had to be implemented in an already well developed water governance system. At the national level three ministries were involved: the Ministry for Water Management and Public Works, with its implementing agency Rijkswaterstaat, the Ministry for Public Housing, Spatial Planning and the Environment, and the Ministry for Agriculture, Nature and Food Quality. At the regional level, the 12 provinces had important planning, coordinating and supervisory tasks and important responsibilities in groundwater management. At the local level, there were some 50 water boards, responsible for managing most surface waters and urban wastewater treatment, and 537 municipalities with a broad range of tasks, including spatial planning and sewer management. All of these bodies had their own policy plans and management plans, but there was no system of river basin management as required by the WFD (cf. art. 13 and 14 WFD and annex VII).

Table 1 provides an overview of the milestones in the implementation of the WFD in the Netherlands. Preparations for the implementation of the WFD started already in 1997. The activities initially focused on the introduction of river basin management. Issues addressed included the incorporation of river basin management plans in the Dutch planning system [25,26], coordination in the different river basins [38], the information needed for the river basin management plans [39] and staff requirements [40]. Occasionally, it was noted that the environmental objectives of the WFD differed from the current ecological standards: the environmental objectives would be binding and apply to all waters, whereas the ecological standards were mere policy objectives for waters with a high nature value only (e.g., [41]).

Table 1. Milestones in the implementation of the WFD in the Netherlands.

\begin{tabular}{|c|c|}
\hline Date & Milestone \\
\hline 1997 & Start preparations for the implementation \\
\hline December 2000 & Entry into force of the WFD \\
\hline November 2002-July 2003 & $\begin{array}{l}\text { Establishment of coordination structures at the } \\
\text { national and the river basin levels }\end{array}$ \\
\hline March 2003 & WFD bill to facilitate implementation \\
\hline November 2003 & Publication of the Aquarein study \\
\hline April 2004 & Publication of the policy note on ambitions \\
\hline April 2005 & Adoption of the WFD bill \\
\hline November 2009 & $\begin{array}{l}\text { Decision Quality Standards and Monitoring Water } \\
2009\end{array}$ \\
\hline December 2009 & Publication first river basin management plans \\
\hline July 2015 & Preliminary ruling of the EU Court in the Weser case \\
\hline December 2015 & Publication second river basin management plans \\
\hline December 2021 & Publication third river basin management plans due \\
\hline December 2027 & $\begin{array}{l}\text { Environmental objectives have to be achieved: with } \\
\text { some exceptions, extension will no longer be possible }\end{array}$ \\
\hline
\end{tabular}

Few people had heard about the WFD [40], and a common opinion among those who had was that water management in the Netherlands was functioning well and achieving the environmental objectives would therefore not be a major issue [42]. However, ideas about EU directives were already shifting as implementation was causing problems [43,44]. For example, in 1998 the Commission had started an infringement procedure against the Netherlands for not correctly implementing the Nitrates directive, and in 2003 the European Court condemned the Netherlands [45]. Consequently, stricter controls on the application of manure had to be introduced.

In March 2003, the minister for water management submitted a bill to Parliament to facilitate the implementation of the WFD (cf. art. 3 WFD). The bill dealt primarily with administrative issues, such as the delimitation of the different river basin districts in the Netherlands. However, MPs from the Christian-democratic party with links to the agricultural sector used the bill as an opportunity to 
criticise the implementation process so far. They saw this process as highly bureaucratic and called for a more open approach (Second Chamber of Parliament, 28 808, No. 5).

Plenary discussion of the bill was scheduled for 2 December 2003, but Parliament removed the bill from the agenda as a result of the publication of the Aquarein study in November [46]. The Aquarein study explored the consequences of the WFD for agriculture and concluded that, to reach a good ecological status, two-thirds of the agricultural area would have to be taken out of production. To reach a very good ecological status, all the agricultural area would have to be taken out of production. The Aquarein study did not consider the possibility of designating water bodies as artificial or heavily modified, extending deadlines and setting lower objectives. Significantly, the study had not been commissioned by the interdepartmental working group coordinating the implementation of the WFD, but by the Ministry of Agriculture on its own. According to one of its authors (a former staff member of the Ministry of Agriculture), the strategic purpose of the study was to break open the bureaucratic implementation process and put the WFD on the political agenda ([42], p. 305). At the conference where the results of the study were presented, the representative of the national agricultural organisation LTO was more outspoken. According to him, the implementation process so far had been left to "civil servants and scientists who care primarily about water quality", but "the implementation of the WFD should not be left to ecologists" ([47], pp. 32-33).

The agricultural lobby was quite effective. In April 2004, the minister for water management published a policy note with the Dutch ambitions concerning the implementation of the WFD [48]. According to the note, the Netherlands would do nothing beyond what is required by "Brussels". Existing land use would not be questioned, and ample use would be made of the possibilities to designate water bodies as artificial or heavily modified and extend deadlines.

The bill to facilitate the implementation of the WFD was finally adopted on 7 April 2005. Despite the delays, the Netherlands managed to adopt the first river basin management plans before the deadline of 22 December 2009. A total of 723 surface water bodies were identified, of which 711 were designated as artificial or heavily modified, as well as 23 groundwater bodies. For 625 surface water bodies and seven groundwater bodies, the deadline for reaching the environmental objectives was extended. Still, many measures for improving the water status were adopted. These included the construction of $2540 \mathrm{~km}$ of nature-friendly banks and the adaptation of 628 water management works to allow fish migration [49]. Most of the Dutch measures were taken by water managers and had a technical character; changes in land use and agricultural practices had not been considered [50].

The river basin management plans and the national programmes of measures were integrated in the existing Dutch water plans. The river basin management plans became an annex to the national water plan, and the programmes of measures consisted of measures included in the State water management plan, the 12 provincial water plans and the water management plans of the then 27 water boards (now 21). To facilitate planning, coordination structures at the national and the river basin level had been set up in November 2002-July 2003. In addition, "active involvement of all interested parties" had been organised (art. 14 WFD). At the national and the river basin levels, this was limited to the exchange of information with organised interest groups in so-called sounding board groups $[9,51,52]$. The agricultural sector and industry were satisfied with this opportunity to monitor the implementation process, probably because they could exert real influence elsewhere, but the environmental NGOs were less satisfied.

The second river basin management plans from 2015 did not bring much news. The coordination in the river basin districts was functioning well and, although several revisions to the plans were made, the Dutch policy with respect to the WFD did not undergo major change. The idea was that, by making use of the possibility to extend deadlines, the environmental objectives had to be reached in 2027 only, and only in the third plans of 2021 would there be a need to consider lowering the objectives. 


\section{The Weser Ruling and the Dutch Reaction}

Then, on 1 July 2015, the European Court of Justice issued its preliminary ruling in the Weser case [1]. In accordance with its own jurisprudence, the Court did not only consider the exact wording of the WFD, but also its objectives and the history of its development. Specifically concerning the no-deterioration objective, the Court stated that the phrase "Member States shall implement the necessary measures" attests to the binding force of that objective. These measures may include refusing authorisation of new projects. Concerning the environmental objectives more generally, the Court referred to the text of art. 4, Section 1, which states that the objectives should be taken into account "in making operational the programmes of measures". This would imply that the objectives entail obligations that must be complied with when approving individual projects. In addition, the Court referred to recital 25, which states that environmental objectives should be set "to ensure" that a good status is achieved and deterioration is prevented, and to art. 1(a), which states that the purpose of the WFD is to establish a framework that "prevent(s) further deterioration and protects and enhances the status of aquatic ecosystems". On this basis, the Court concluded that the environmental objectives do "not simply set out, in programmatic terms, mere management-planning objectives, but has (sic) binding effects" ([1], point 43). Consequently, Member States have to refuse authorisation for an individual project if it may cause deterioration of the water status or jeopardise the attainment of a good water status or potential (see also [18]).

The most problematic aspect of the ruling for the Netherlands is that individual projects have to be assessed against the environmental objectives. This is currently not done. The environmental objectives have been transposed into a Cabinet order, the Decision Quality Standards and Monitoring Water 2009 (DQMW 2009). The DQMW 2009 includes the water quality standards from the Environmental Quality Standards Directive and the Groundwater Directive, which define the "good chemical status" of surface and groundwater. For the good ecological status, the DQMW 2009 refers to the definitions in the WFD and to the official Dutch monitoring programme (Ministerial regulation monitoring WFD). This monitoring programme in turn refers to the so-called Ecological Quality Ratios system, developed by STOWA, a foundation of the water boards that funds water research [53]. Water bodies can be designated as artificial or heavily modified, deadlines can be extended and lower objectives can be set only on the grounds mentioned in the WFD. For the largest surface waters, the so-called State waters, the environmental objectives are set in the State water management plan, and for the other waters in the provincial water plan (art. 2, 3 and 6 DQMW 2009).

The minister for water management, the provinces and the water boards together have to ensure that the environmental objectives are reached. They have to include measures for reaching these objectives in their water plans and subsequently implement these measures (art. 4.1 and 7.1 DQMW 2009, art. 8.1 Water decision (a Cabinet order)). There is, however, no legal obligation to implement measures included in municipal water plans. Moreover, new projects may be proposed that were not considered when the water plans were drafted, such as new industrial plants or housing estates. Before such projects can be authorised, the effects on the quality of the receiving waters have to be assessed, but only the effects of point source pollution are considered, not diffuse pollution, and the effects of morphological alterations are not assessed at all (art. 9.2 and annex Regulation environmental law, [4]). Furthermore, achieving the environmental objectives may require action outside of the water sector, such as changes in land use or agricultural policy [2]. According to Dutch planning law, water managers have to be consulted in the development of land-use plans, but they lack any formal powers to stop new developments. Coordination is even weaker with respect to agricultural policy.

The Dutch approach to the environmental objectives of the WFD can be explained by three factors. First, there is the Aquarein study and lobbying by the agricultural sector, discussed in the previous section. Secondly, there were important economic and political developments in the early 2000s. In 2008, the Netherlands faced the global financial crisis and in 2010/2011 the national budgets for implementing the WFD and nature policy were cut significantly. In addition, the Netherlands got a new cabinet in October 2010, with a minister for agriculture and nature (Hein Bleker) who was very 
supportive agriculture and critical of nature protection. As he recently told the Dutch newspaper NRC (27 December 2019), he would have cut the budget for nature protection even without the financial crisis.

Thirdly, the implementation of the WFD followed the approach developed for implementing the EU air quality directive. In the early 2000s, the Netherlands had experienced problems with meeting the standards from this directive, which had been transposed into Dutch law as assessment criteria for new projects. Subsequently, the Dutch courts nullified several authorisations for new projects [43]. In response, national government developed the so-called "programmatic approach". This involves the development of a programme of measures that should ensure that environmental quality standards are met while creating space for new development. New projects are no longer assessed against the environmental quality standards directly and can be authorised if they fit in the programme. Programmatic approaches have been developed not only for air quality, but also for Nitrogen deposition in Natura 2000 areas (established under the Habitat Directive) and for the WFD [54-56]).

The preliminary ruling of the European Court of Justice of 7 November 2018 concerning the Dutch Programmatic Approach Nitrogen and the subsequent decision by the Dutch Council of State of 29 May 2019 have made it crystal clear that a programmatic approach has to comply with European law too $[57,58]$. The Programmatic Approach Nitrogen does not correctly implement the requirement form the Habitat directive to compensate for the negative effects of new activities and hence may not be used to authorise new activities [59]. As a result, the Netherlands are currently facing a "Nitrogen crisis". Many building projects are on hold, agriculture will face stricter controls and builders and farmers are organising large demonstrations and blocking highways.

Back in 2015, a question was asked in Parliament to the minister for water management concerning the implications of the Weser case for the Netherlands. According to the minister, the ruling supported the Dutch approach for implementing the WFD. The Court had decided that the environmental objectives have to be applied to individual projects, but not how this should be done, and it did not rule out a programmatic approach [5]. That in itself is correct. However, the fact that a programmatic approach is not ruled out does not mean that the Dutch approach is correct. As explained above, this is questionable.

The European Commission has not (yet?) started an infringement procedure against the Netherlands for incorrect implementation of the WFD. However, it is critical of the Netherlands. In its evaluation of the river basin management plans for 2015-2021, the European Commission recommended the Netherlands to complete the assessment of the effectiveness of the existing agricultural measures and to identify which additional measures are needed to achieve the objectives of the WFD. Moreover, it expressed doubts about the large number of exemptions and their justification ([60], p. 19). According to analyses by the Netherlands Environmental Assessment Agency, additional measures will be needed to meet a good water status or potential by 2027 [61]. If these are not taken, the only option left is to lower the environmental objectives. This will have to be justified satisfactory in the river basin management plans (art. 4 WFD).

\section{The Power of Law}

The implementation of the WFD in the Netherlands can be read in different ways. One reading is purely political: implementation was determined by national politics and more specifically the relative strength of different interest groups. The WFD itself is a legal document, but it is also the result of a political process.

In this section, I give a different reading. While recognising the importance of politics, the implementation of the WFD and river basin management more generally also have a legal character. Following Bourdieu [23], I approach law neither as a purely formal system of norms, nor as a mere instrument of power, but as a distinct social field with its own players and structure (see also [62]). At the top in this field, in as far as European law is concerned, is the European Court of 
Justice. They have the final say as to the meaning and practical implications of EU law. Below the European Court are different rungs of national courts and the many barristers, attorneys academics and civil servants who deal with European law and for whom the European Court is a central point of reference (cf. the definition of law by O.W. Holmes jr: "law is the prophecy of what the courts will do" ([63], p. 457)). The central stake in the juridical field is the control of legal texts: who can give the correct interpretation of the regulations and jurisprudence? This depends on the socially recognised legal expertise or "juridical capital" that the different players in the field possess. This in turn depends on their formal qualifications (possession of a law degree) and their position (e.g., high court judge or law professor).

Historically, the development of the juridical field was tied up with the development of the modern State. In France, personal rule by the King was first strengthened by impersonal rules on for instance registration and taxation, resulting in the absolutist monarchy of the 17th and 18th Centuries, and then replaced by impersonal rule in the form of Parliamentary democracy and bureaucracy as a result of the French revolution [24]. Other countries followed somewhat different trajectories, but, in most, the modernisation process involved the replacement of customary law by statutory law and lay judges by professional lawyers and the development of specialised courts of law, either because existing government bodies lost their non-judicial functions or because they were newly established (see on The Netherlands [64,65]).

The juridical field is still linked with politics. Judges often have a similar social background as politicians [23], appointments are often highly political (e.g., appointments to the Supreme Court of the USA), and the materials they work with include regulations that are the result of political processes. However, they interpret the regulations in their own way, formulate their own legal principles, and develop and use their own jurisprudence (cf. footnote 2). They may also overturn political decisions. However, the juridical field can only function in this way "to the extent that the law is socially recognized and meets with agreement $(. .$.$) because it corresponds, at least apparently,$ to real needs and interests" ([23], p. 840). Put differently, it needs social and political support. If it loses support, courts may lose their independence, as is happening in Hungary since 2010 and Poland since 2015 [66]. And if the EU law loses support, Member States may decide to leave the European Union, as the United Kingdom recently did.

Paradoxically, the better the juridical field serves social and political interests, the more independence it enjoys on a daily basis. However, this does not mean that law serves only the interests of those in power. At its best, law provides stability and predictability, promotes freedom, and secures equal treatment. It can also legitimise the exercise of power under the "mask" of law [33], but only if those in power are seen as respecting the law and if the law has some benefits for the less powerful as well [24]. Effectively, by restraining themselves, those in power can make their power more bearable and acceptable and thereby more secure.

Zooming in on the Netherlands, we can observe that interest in EU matters is generally low, but the number of people wanting to stay in the EU is far larger than the number of people wanting to leave [67]. The European Court of Justice is generally respected and national courts are independent and can overturn political decisions. Recent examples of the latter include the decisions of the district court of The Hague of 24 June 2015 and the Court of Appeal on 9 October 2018 in the Urgenda case, which required the State to reduce greenhouses gas emissions by at least $25 \%$ in 2020 compared to 1990 in order to mitigate climate change [68]. In national politics, the law may be ignored temporarily or, more commonly, interpreted restrictively to fit current policy, but it takes precedence again when political decisions are overturned. This has happened with respect to Programmatic Approach Nitrogen, mentioned above, and it may happen in the future with respect to the WFD.

For understanding river basin management, it is essential to know not only what the law currently says, but also who make and interpret the law, who control and enforce it, and what their relations with politics are. To answer these questions, it is necessary to open up the legal black box. 


\section{Conclusions}

This article set out to describe the implementation of the WFD in the Netherlands and show the importance of law and especially the courts in river basin management. Although many measures for improving the status of the waters have been taken, the Netherlands do not comply with the preliminary ruling of the European Court of Justice in the Weser case, which requires that new developments are assessed against the environmental objectives of the WFD and that authorisation is refused if they jeopardise the achievement of these objectives. This lack of compliance can be explained by a combination of (a) lobbying by especially the agricultural sector; (b) a political climate in which environmental issues got a lower priority; and (c) previous problems with implementing EU directives. For the time being, this lack of compliance does not cause problems comparable to the current "Nitrogen crisis", but, in the future, the European Court of Justice may force the Netherlands to comply.

The implementation of the WFD in the Netherlands shows that, in river basin management, law and politics blend. It also shows that law cannot be reduced to politics, provided the juridical field - the courts and the lawyers-functions relatively independently, as it does in the Netherlands. Law may simultaneously legitimise and constrain the use of power. Anyone interested in river basin management should therefore develop a good understanding of the current law and its functioning.

Funding: This research received no external funding.

Acknowledgments: In this article I argued that law is a distinct social field with its own form of capital. The same can be said of science [69]. In the Netherlands, the main form of scientific capital currently is the ability to attract external funding. This reduces the possibilities for independent and truly innovative research. Dutch universities do receive lump-sum funding for so-called "free research", but these funds too are spent increasingly on priorities set by funding agencies, to complement external funding and because researchers specialising in these priorities are more likely to attract external funding and hence make a career in science than researchers who do not. The writing of this article was funded from my university's lump-sum funding, so by the Ministry of Education, Culture and Science and ultimately the Dutch taxpayer. I would like to thank them for this. The article is not linked directly to a research priority of a funding agency, but most of the sources used were externally funded. In fact, no researcher is completely independent from the social context in which he or she functions.

Conflicts of Interest: The author declares no conflict of interest.

\section{References}

1. European Court of Justice. Judgement of the Court (Grand Chamber) of 1 July 2015 in Case C-461/13; Bund für Umwelt und Naturschutz Deutschland eV versus Bundesrepublik Deutschland, and as joined party Freie Hansestadt Bremen (ECLI:EU:C:2015:433); European Court of Justice: Luxembourg, 2015.

2. Squintani, L.; Plambeck, E.; van Rijswick, M. Strengths and Weaknesses of the Dutch Implementation of the Water Framework Directive. J. Eur. Environ. Plan. Law 2017, 14, 269-293. [CrossRef]

3. Mostert, E. Nederlands Waterrecht Voor Niet-Juristen; TU Delft Open: Delft, The Netherlands, 2019. [CrossRef]

4. Rijkswaterstaat. Handboek Immissietoets 2016; Ministerie van Infrastructuur en Milieu: The Hague, The Netherlands, 2016.

5. Minister for Infrastructure and the Environment. Annex to the Proceedings of the Second Chamber of Parliament 2015-2016, No. 273. 2015. Available online: https://zoek.officielebekendmakingen.nl (accessed on 9 October 2020).

6. Uitenboogaart, Y.; Kempen, J.J.H.v.; Rijswick, H.F.M.W.v.; Wiering, M.A. The Implementation of the WFD in the Netherlands; The Meuse River Basin District and the Dommel Catchment. In Dealing with Complexity and Policy Discretion; A Comparison of the Implementation Process of the European Water Framework Directive in Five Member States; Uitenboogaart, Y., Kempen, J.J.H.v., Wiering, M.A., Rijswick, H.F.M.W.v., Eds.; Sdu Uitgevers: The Hague, The Netherlands, 2009; pp. 57-83.

7. Borowski-Maaser, I.; Mostert, E.; Junier, S.J. Innovative Instruments and Institutions in Implementing the Water Framework Directive: Lessons Learnt for the Second Implementation Cycle of the WFD. Case Study Cross Comparison \& the QuickScan Training Package. 2010. Available online: http://resolver.tudelft.nl/uuid: 761460e5-ea78-45f2-a996-8ded28ef8e3f (accessed on 9 October 2020). 
8. Junier, S.; Borowsk, I.; Bouleau, G.; Interwies, E.; Mostert, E. Implementing the Water Framework Directive: Lessons for the second planning cycle. In The Water Framework Directive: Action Programmes and Adaptation To Climate Change; Quevauviller, P., Borchers, U., Thomson, K.C., Simonart, T., Eds.; RSC Publishing: Cambridge, UK, 2011; pp. 80-98.

9. Ten Heuvelhof, E.; Van der Heijden, J.; Van der Arend, S.; Broekhans, B.; Van Bueren, E.; Harteveld, C. Evaluatie van de Implementatie van de Kaderrichtlijn Water; Delft University of Technology: Delft, The Netherlands 2010.

10. Raadgever, G.; Dieperink, C.; Driessen, P.; Smit, A.; Van Rijswick, H. Uncertainty management strategies: Lessons from the regional implementation of the Water Framework Directive in the Netherlands. Environ. Sci. Policy 2011, 14, 64-75. [CrossRef]

11. Liefferink, D.; Wiering, M.; Uitenboogaart, Y. The EU Water Framework Directive: A multi-dimensional analysis of implementation and domestic impact. Land Use Policy 2011, 28, 712-722. [CrossRef]

12. Behagel, J.H. The Politics of Democratic Governance: The Implementation of the Water Framework Directive in the Netherlands. Ph.D. Thesis, Wagening University, Wageningen, The Netherlands, December 2012.

13. Santbergen, L. Ambiguous Ambitions in the Meuse Theatre: The Impact of the Water Framework Directive on Collective-Choice Rules for Integrated River Basin Management; Uitgeverij Eburon: Delft, The Netherlands, 2013.

14. Junier, S.; Mostert, E. A decision support system for the implementation of the Water Framework Directive in the Netherlands: Process, validity and useful information. Environ. Sci. Policy 2014, 40, 49-56. [CrossRef]

15. Junier, S.J. Modelling Expertise; Experts and Expertise in the Implementation of the Water Framework Directive in the Netherlands. Ph.D. Thesis, Delft University of Technology, Delft, The Netherlands, 2017.

16. Van der Arend, S.; Santbergen, L.; Wiering, M.; Behagel, J. Tien Jaar Ervaringen met de Kaderrichtlijn Water, Ambities en Ambivalenties Rondom een Europese Richtlijn; Eburon: Delft, The Netherlands, 2010.

17. Kruyt, R.L. De Kaderrichtlijn water: Resultaatverplichting of inspanningsverplichting? In Nieuwe Mogelijkheden tot Regulering van Waterkwaliteitseisen in Nederland; Backes, C.W., Kruyt, R.L., Rijswick, H.F.M.W.v., Eds.; Centrum voor Omgevingsrecht en -beleid: Utrecht, The Netherlands, 2007; pp. 75-134.

18. Rijswick, H.F.M.W.; Backes, C.W. Ground breaking landmark case on environmental quality standards?; The consequences of the CJEU 'Weser judgement' (C-461/13) for water policy and law and quality standards in EU environmental law. J. Eur. Environ. Plan. Law 2015, 363-377. [CrossRef]

19. Marmor, A. The Pure Theory of Law. In The Stanford Encyclopedia of Philosophy; Zalta, E.N., Nodelman, U., Allen, C., Anderson, R.L., Eds.; Stanford University: Stanford, CA, USA, 2016.

20. Hunt, A. Marxist Theory of Law. In A Companion to Philosophy of Law and Legal Theory, 2nd ed.; Patterson, D., Ed.; Wiley-Blackwell: Chichester, UK, 2010; pp. 350-360.

21. Ostrom, E. Governing the Commons: The Evolution of Institutions for Collective Action, 1st ed.; Cambridge University Press: Cambridge, UK, 1990.

22. Ostrom, E. Understanding Institutional Diversity; Princeton University Press: Princeton, NJ, USA, 2005.

23. Bourdieu, P. The Force of Law: Toward a Sociology of the Juridical Field. Hastings Law J. 1987, 38, 805-853.

24. Bourdieu, P. On the State; Lectures at the Collège de France 1989-1992; Wiley \& Sons: New York, NY, USA, 2014.

25. RBA Centre TU Delft; WL|Delft Hydraulics. Onderzoek rond de Kaderrichtlijn Waterbeheer; Inventarisatie/Onderzoek Rond de Kaderrichtlijn Waterbeheer; De Stroomgebiedsbenadering en het Nederlandse Waterbeheer. Deel 1: Inventarisatie; WL/delft Hydraulics/RIZA: Delft/Lelystad, The Netherlands, 1997. Available online: http://resolver.tudelft.nl/uuid:644ec903-d820-48c5-8c88-26199c8d66c1 (accessed on 9 October 2020).

26. RBA Centre TU Delft; WL|Delft Hydraulics. De Kaderrichtlijn Water en het Nederlandse Stroomgebiedbeheer/Onderzoek rond de Kaderrichtlijn Waterbeheer; De Stroomgebiedsbenadering en het Nederlandse Waterbeheer. Deel 2: Case Study; WL/delft Hydraulics/RIZA: Delft/Lelystad, The Netherlands, 1998. Available online: http://resolver.tudelft.nl/ uuid:715312f0-9f34-40b0-a948-9e2cbfea8b9a (accessed on 9 October 2020).

27. Working Group 2.9-Public Participation. Guidance on Public Participation in relation to the Water Framework Directive; Office for Official Publications of the European Communities: Luxembourg, 2003.

28. Page, B.; Kaika, M. The EU Water Framework Directive: Part 2. Policy innovation and the shifting choreography of governance. Eur. Environ. 2003, 13, 328-343. [CrossRef]

29. Rahaman, M.M.; Varis, O.; Kajander, T. EU Water Framework Directive vs. Integrated Water Resources Management: The Seven Mismatches. Int. J. Water Resour. Dev. 2004, 20, 565-575. [CrossRef]

30. Steyaert, P.; Ollivier, G. The European Water Framework Directive: How Ecological Assumptions Frame Technical and Social Change. Ecol. Soc. 2007, 12. [CrossRef] 
31. Bouleau, G.; Pont, D. Did you say reference conditions? Ecological and socio-economic perspectives on the European Water Framework Directive. Environ. Sci. Policy 2015, 47, 32-41. [CrossRef]

32. Moss, B. The Water Framework Directive: Total environment or political compromise? Sci. Total Environ. 2008, 400, 32-41. [CrossRef]

33. Burley, A.-M.; Mattli, W. Europe before the court: A political theory of legal integration. Int. Organ. 1993, 47, 41-76. [CrossRef]

34. Cohen, A.; Vauchez, A. The social construction of law: The European Court of Justice and its legal revolution revisited. Annu. Rev. Law Soc. Sci. 2011, 7, 417-431. [CrossRef]

35. European Commission. Monitoring the Application of Union Law 2018 Annual Report; Part II: Policy Areas; European Commission: Brussels, Belgium, 2019.

36. European Court of Justice. Judgement of the Court (First Chamber) of 31 May 2018 in Case C-251/17; European Commission v Italian Republic (ECLI:EU:C:2018:358); European Court of Justice: Luxembourg, 2018.

37. Kaika, M.; Page, B. The EU Water Framework Directive: Part 1. European Policy-making and the changing topography of lobbying. Eur. Environ. 2003, 13, 314-327. [CrossRef]

38. Werkgroep Bestuurlijke Organisatie Nationaal. Advies Inzake de Bestuurlijke Organisatie Nationaal Voor de Uitvoering van de Kaderrichtlijn Water (Periode 2002-2015); REF IKW 380; Projectteam Implementatie Kaderrichtlijn Water: Den Haag, The Netherlands, 2001.

39. Bosma, J.; Busch, S. Pilots Kaderrichtlijn Water Eems en Midden-Holland; RIZA: Lelystad, The Netherlands, 2002.

40. Bertens, P.H.; Dekkers, M.J.A.; Dircke, P.T.M.; Slobbe, E.J.J. Consequenties Europese Kaderrichtlijn Water Voor Provincies en Waterschappen; Arcadis: Den Haag, The Netherlands, 2002.

41. Busch, S. (Ed.) Kaderrichtlijn Water pilot Midden-Holland; Background Report; RIZA: Lelystad, The Netherlands, 2002.

42. Behagel, J.; Turnhout, E. Democratic legitimacy in the implementation of the Water Framework Directive in the Netherlands: Towards participatory and deliberative norms? J. Environ. Policy Plan. 2011, 13, 297-316. [CrossRef]

43. Neven, M.G.G.; Turnhout, E.; Bogaardt, M.J.; Kistenkas, F.H.; Van der Zouwen, M.W. Richtingen Voor Richtlijnen; Interacties Tussen Nederland en de Europese Commissie in de Implementatie van Europese Milieurichtlijnen; Wageningen Universiteit: Wageningen, The Netherlands, 2006.

44. Beunen, R.; Van Assche, K.; Duineveld, M. Performing failure in conservation policy: The implementation of European Union directives in the Netherlands. Land Use Policy 2013, 31, 280-288. [CrossRef]

45. European Court of Justice. Judgment of the Court (Sixth Chamber) of 2 October 2003 in Case C-322/00; Commission of the European Communities v Kingdom of The Netherlands (ECLI:EU:C:2003:532); European Court of Justice: Luxumbourg, 2003.

46. Bolt, F.; Bosch, R.; Brock, T.; Hellegers, P.; Kwakernaak, C.; Leenders, D.; Schoumans, O.; Verdonschot, P. Aquarein; Gevolgen van de Europese Kaderrichtlijn Water Voor Landbouw, Natuur, Recreatie en Visserij; Research Report; Wageningen University: Wageningen, The Netherlands, 2003.

47. Hagendoorn, A. (Ed.) De Kaderrichtlijn Water en een Vitaal Platteland; Verslag van de werkconferentie op 28 november 2003; Expertisecentrum LNV: Ede, The Netherlands, 2004. Available online: https://edepot.wur.nl/116386 (accessed on 9 October 2020).

48. Deputy Minister of Transport, Public Works and Water Management. Nota pragmatische Implementatie Europese Kaderrichtlijn Water in Nederland; van beelden naar betekenis (Kamerstukken II 2003/4, 28 808, nr 12). 2004. Available online: https://zoek.officielebekendmakingen.nl (accessed on 9 October 2020).

49. Projectteam stroomgebiedbeheerplannen. Stroomgebiedbeheerplannen 2009-2015; Samenvatting Eems, Maas, Rijndelta en Schelde; Minsterie van V\&W, Ministerie van VROM en Ministerie van LNV: The Hague, The Netherlands, 2009.

50. Van der Wal, B.; Waajen, G. De Kaderrichtlijn Water; Het vermeende walhalla voor de aquatische ecologie? In Tien Jaar Ervaringen Met de Kaderrichtlijn Water, Ambities en Ambivalenties Rondom een Europese Richtlijn; Van den Arend, S., Santbergen, L., Wiering, M., Behagel, J., Eds.; Eburon: Delft, The Netherlands, 2010; pp. 7-17.

51. Behagel, J.; van der Arend, S. What institutions do: Grasping participatory practices in the Water Framework Directive. In Forest and Nature Governance: A Practice Based Approach; Arts, B.J.M., Behagel, J.M., van Bommel, S., de Koning, J., Turnhout, E., Eds.; Springer: Dordrecht, The Netherlands, 2012; pp. 69-88. 
52. Van der Heijden, J.; ten Heuvelhof, E.; Broekhans, B.; van der Arend, S.; van Bueren, E.; Harteveld, C.; van Ruijven, T. Contrasting stories on overcoming governance challenges: The implementation of the EU Water Framework Directive in the Netherlands. Local Environ. 2014, 19, 318-333. [CrossRef]

53. Van der Molen, D.T.; Pot, R.; Evers, C.H.M.; Van Herpen, F.C.J.; Van Nieuwenburgh, L.L.J. Referenties en Maatlatten voor Natuurlijke Watertypen voor de Kaderrichtlijn Water 2021-2027; Stowa: Amersfoort, The Netherlands, 2018.

54. Boeve, M.N.; Groothuijse, F.A.G. Programmatische aanpak in de Omgevingswet: Ruimte voor ontwikkeling, waarborgen voor kwaliteit? Wet eenvoudig beter, amvb diffuser en complexer? Tijdschr. Omgevingsrecht 2014, 71-80. [CrossRef]

55. Kegge, R.; Boogaard, G. De programmatische aanpak getoetst. Tijdschr. Milieu Recht 2018, 45, 96-104.

56. Van Rijswick, H.; Freriks, A. Programmatische aanpak stikstof en programmatische aanpak water: Van tweeën een? Tijdschr. Agrar. Recht 2015, 2015, 399-415.

57. European Court of Justice. Judgement of the Court (Second Chamber) of 31 May 2018 in the Cases C-293/17 and C-294/17; Coöperatie Mobilisation for the Environment UA and Vereniging Leefmilieu v College van gedeputeerde staten van Limburg and College van gedeputeerde staten van Gelderland (ECLI:EU:C:2018:882); European Court of Justice: Luxumbourg, 2018.

58. Raad van State. Uitspraak van 29 mei 2019 in het geding tussen Stichting Werkgroep Behoud de Peel en het college van gedeputeerde staten van Noord-Brabant (ECLI:NL:RVS:2019:1603); Raad van State: The Hague, The Netherlands, 2019.

59. Squintani, L. Balancing nature and economic interests in the European Union: On the concept of mitigation under the Habitats Directive. Rev. Eur. Comp. Int. Environ. Law 2019, 1-9. [CrossRef]

60. European Commission. Second River Basin Management Plans, First Flood Risk Management Plans-Member State: The Netherlands; Commission Staff Working Document; European Commission: Brussel, Belgium, 2019.

61. Van Gaalen, F.; Osté, L.; Van Boekel, E. Nationale Analyse Waterkwaliteit, Onderdeel van de Delta-Aanpak Waterkwaliteit; Tussentijdse Resultaten en Conclusies; PBL, Planbureau voor de Leefomgeving: Den Haag, The Netherlands, 2019.

62. Dezalay, Y.; Madsen, M.R. The force of law and lawyers: Pierre Bourdieu and the reflexive sociology of law. Annu. Rev. Law Soc. Sci. 2012, 8, 433-452. [CrossRef]

63. Holmes, O.W., Jr. The Path of the Law. Harv. Law Rev. 1897, 10, 457-462.

64. Monté ver Loren, J.P.d.; Spruit, J.E. Hoofdlijnen uit de Ontwikkeling der Rechterlijke Organisatie in de Noordelijke Nederlanden tot de Bataafse Omwenteling, 6e Impr.; Kluwer: Deventer, The Netherlands, 1982.

65. Le Bailly, M.-C. Recht voor de Raad; Rechtspraak voor het Hof van Holland, Zeeland en West-Friesland in het Midden van de Vijftiende Eeuw; Verloren: Hilversum, The Netherlands, 2001.

66. Kovács, K.; Scheppele, K.L. The fragility of an independent judiciary: Lessons from Hungary and Poland-And the European Union. Communist Post Communist Stud. 2018, 51, 189-200. [CrossRef]

67. Dekker, P.; den Ridder, J.; Schout, A. Wat Willen Nederlanders van de Europese Unie?; Een Verkenning met Enquêtes, een Onlinedialoog en Focusgroepen; Sociaal en Cultureel Planbureau: Den Haag, The Netherlands, 2019.

68. Mayer, B. The State of the Netherlands v. Urgenda Foundation: Ruling of the Court of Appeal of The Hague (9 October 2018). Transnatl. Environ. Law 2019, 8, 167-192. [CrossRef]

69. Bourdieu, P. Science de la Science et Réflexivité: Cours du Collège de France, 2000-2001; Raisons d'agir: Paris, France, 2001.

Publisher's Note: MDPI stays neutral with regard to jurisdictional claims in published maps and institutional affiliations.

(C) 2020 by the author. Licensee MDPI, Basel, Switzerland. This article is an open access article distributed under the terms and conditions of the Creative Commons Attribution (CC BY) license (http://creativecommons.org/licenses/by/4.0/). 